\title{
PENGARUH SUPERVISI KEPALA SEKOLAH TERHADAP KINERJA GURU DI SMP K 1 PENABUR PASAR BARU JAKARTA PUSAT
}

\author{
${ }^{1}$ Mohammad Ramadona dan ${ }^{2}$ Rian Wibowo \\ ${ }^{1}$ Dosen Program Studi Pendidikan Ekonomi Universitas Indraprasta PGRI \\ ${ }^{2}$ Mahasiswa Program Studi Pendidikan Ekonomi Universitas Indraprasta PGRI \\ Email. Mohammad_ramadona@gmail.com
}

\begin{abstract}
Abstrak
Penelitian ini bertujuan untuk mengetahui pengaruh supervisi kepala sekolah terhadap kinerja guru di SMP K 1 Penabur Pasar Baru Jakarta Pusat pada bulan mei 2014. Metode penelitian yang digunakan adalah survey dengan menggunakan teknik pengumpulan data penelitian berupa wawancara, observasi, dan menggunakan kuesioner (angket). Berdasarkan hasil pengujian hipotesis disimpulkan bahwa supervisi kepala sekolah berpengaruh signifikan dan positif terhadap kinerja guru pada guru SMP K 1 Penabur Pasar Baru Jakarta Pusat dengan hasil perhitungan korelasi $r=0,7045$. Hasil pengkuadratan $r^{2}=49,63 \%$ menggambarkan adanya pengaruh supervise kepala sekolah terhadap kinerja guru. Pengaruh tersebut dibuktikan dengan hasil uji $\mathrm{t}$ bahwa $\mathrm{t}$ hitung 5,7026> $\mathrm{t}$ tabel $(33: 0,025)$ sebesar 2,021 sehingga $\mathrm{H}_{\mathrm{o}}$ ditolak dan $\mathrm{H}_{\mathrm{a}}$ diterima.
\end{abstract}

Kata kunci: Kinerja Kerja, Supervisi Kepala Sekolah.

\section{PENDAHULUAN}

Peradaban bangsa sedang dihadapkan pada berbagai tantangan, hal ini terjadi karena gencarnya informasi, dan lepasnya sekat antara bangsa lewat teknologi informasi. Untuk menghadapi tantangan ini bagi dunia pendidikan, maka peran guru kian strategis untuk mengambil salah satu peran yang menopang pada tegaknya peradaban manusia Indonesia dimasa yang akan datang. Harapan ini menjadi suatu keniscayaan, karena dalam urusan pendidikan tidak cukup dengan verbalitas tetapi dibutuhkan kerja profesional, kreatifitas dan efektifitas untuk mencapai cita-cita yang didambakan. Sebagaimana telah dipahami secara meluas bahwa guru merupakan pekerjaan yang amat mulia. Guru berhadapan dengan anak-anak manusia yang akan menentukan masa depan bangsa. Hal ini menunjukan bahwa, betapa berat beban yang disandang oleh guru.

Peran guru yang strategis, menuntut kerja guru yang professional, dan mampu mengembangkan ragam potensi yang terpendam dalam diri peserta didik. Sedemikian besar peran guru dalam melakukan perubahan terhadap peradaban lewat anak didik yang akan menuntut kemajuan masa depan. Tetapi disisi lain guru dihadapkan pada sejumlah permasalahan antara lain memantapkan kompetensi guru sesuai UU No.14 tahun 2005 yaitu kompetensi pedagogik, kompetensi profesional, kompetensi kepribadian, dan 
kompetensi sosial. Tentu ada diantara guru sulit untuk memahaminya apalagi mengimplementasikan. Di atas semua kesulitan ini tentu saja guru membutuhkan bantuan untuk mengatasi kesulitannya. Orang-orang yang paling dekat dan dipandang mampu untuk membantu mengatasi kesulitan guru tersebut adalah kepala sekolah dan pengawas sekolah melalui kegiatan supervisi.

Supervisi merupakan inspeksi, pemilikan, pengawasan, monitoring, dan penilaan atau evaluasi pengajaran yang ditunjukan untuk perbaikan pengajaran, perbaikan itu dilakukan melalui peningkatan kemampuan profesional guru dalam melaksanakan tugasnya. Fungsinya adalah untuk membantu mendorong dan memberikan keyakinan kepada guru, bahwa proses belajar mengajar dapat dan harus diperbaiki serta pengembangan berbagai pengalaman, pengetahuan, sikap dan keterampilan guru harus dibantu secara professional sehingga guru tersebut dapat berkembang dalam pekerjaannya. Peranannya yaitu berusaha untuk melakukan perubahan kecil dan untuk mengubah secara lebih intensif praktek-praktek pengajaran tertentu.

Serangkaian kegiatan membentuk guru mengembangkan kemampuannya, maka dalam melaksanakannya supervisi terhadap guru perlu diadakan kemampuan guru, sehingga dapat ditetapkan aspek mana yang perlu dikembangkan dan bagaimana cara yang tepat dalam proses mengembangkannya. Artinya kepala sekolah dapat memberikan penilaian performasi guru dalam mengelola penampilan guru dalam proses belajar mengajar. Namun, satu hal yang harus ditegaskan, bahwa setelah melakukan penilaian penampilan guru bukan berarti selesai tentang kegiatan supervisi, tetapi harus dilanjutkan dengan perancangan dan pelaksanaan pengembangan kemampuannya. Hal-hal yang perlu diperhatikan dan perlu dikembangkan pada setiap guru oleh kepala sekolah sebagai supervisor adalah kepribadian guru, peningkatan profesi secara kontiniu, proses pembelajaran, pendalaman materi pembelajaran, keragaman kemampuan guru dalam bekerja sama dengan masyarakat.

Mengingat peran serta guru dalam lembaga pendidikan, guru dituntut untuk bekerja dengan memberikan pelayanan sebaik-baiknya kepada pengguna sekolah seperti siswa, orang tua dan masyarakat. Kinerja guru merupakan sasaran penting dalam manajemen sumber daya manusia, karena secara langsung maupun tidak langsung akan mempengaruhi kualitas kerja. Sesuatu gejala yang dapat membuat rusaknya kondisi 
lembaga/yayasan pendidikan adalah rendahnya kinerja guru dimana timbul suatu gejala seperti absen, malas bekerja, banyak mengeluh, rendahnya prestasi kerja, rendahnya kualitas mengajar, indisipliner guru, dan gejala negative lainnya. Sebaliknya kinerja yang tinggi diingikan oleh kepala sekolah karena dapat dikaitkan dengan positif yang diperlukan. Kinerja yang tinggi menandakan bahwa sebuah lembaga/yayasan pendidikan telah dikelola dengan baik.

Kinerja yang tinggi menunjukkan kesesuaian antara harapan guru dengan imbalan yang disediakan oleh lembaga/yayasan. Meningkatkan kinerja bagi guru merupakan hal yang sangat penting, karena menyangkut masalah kerja guru yang merupakan salah satu langkah dalam meningkatkan mutu pelayanan kepada siswa. Usaha meningkatkan kemampuan guru dalam melaksanakan proses belajar mengajar perlu secara terus menerus mendapatkan perhatian dari penanggung jawab sistem pendidikan. Peningkatan ini akan lebih berhasil apabila dilakukan oleh guru dengan kemauan dan usaha mereka sendiri. Namun sering kali guru masih memerlukan bantuan dari orang lain, karena ia belum mengetahui atau belum memahami jenis, prosedur, dan mekanisme memperoleh berbagai sumber yang sangat diperlukan dalam usaha meningkatkan bantuan kepada guru dalam mencerdaskan dan melaksanakan peningkatan professional mereka dengan memanfaatkan sumber yang tersedia.

\section{TINJAUAN PUSTAKA}

\section{Deskripsi Kinerja guru}

Secara etismologis istilah kinerja merupakan terjemahan dari kata performance yang berasal dari kata to perform yang memiliki arti yaitu (1) prestasi, (2) pelaksanaan, (3) pencapaian dan (4) unjuk kerja atau penampilan kerja (Barnawi dan Arifin 2014:11). Menurut Kamus Bahasa Indonesia (2014:422), kinerja adalah teknik daya operasional atau kerja; prestasi yang diperlihatkan dan sesuatu yang dicapai. Kinerja merupakan tindakan atau tingkah laku untuk mencapai prestasi kerja. Supardi (2013:45) mengungkapkan bahwa yang dimaksud dengan kinerja adalah suatu kegiatan yang dilakukan untuk melaksanakan dan menyelesaikan tugas tertentu dengan penuh tanggung jawab sesuai dengan harapan dan tujuan yang telah ditetapkan sebelumnya.

Whitmore (1997) dalam Uno dan Lamatenggo (2012:60) mengemukakan —kinerja adalah suatu perbuatan, suatu prestasi atau apa yang diperlihatkan seseorang melalui keterampilan yang nyata. Berdasarkan pandangan ini, kinerja merupakan pengekspresian 
potensi diri yang menyeluruh dari individu tersebut, karena jika tidak maka potensi yang dimilliki oleh individu tersebut akan berlangsung tidak optimal. Sedangkan menurut Rachmawati (2013:16), kinerja adalah tingkat keberhasilan seseorang atau kelompok orang dalam melaksanakan tugas dan tanggung jawabnya serta kemampuan untuk mencapai tujuan dan standar yang telah ditetapkan.

Kinerja guru merupakan tingkat keberhasilan guru dalam menyelesaikan pekerjaannya. Kinerja guru tidak hanya ditunjukkan oleh hasil kerja akan tetapi juga ditunjukkan oleh perilaku dalam bekerja, mulai dari perencanaan pembelajaran, dalam pelaksanaan pembelajaran dikelas dan proses evaluasi atau penilaian hasil belajar siswa (Priansa, 2014:79)

Sementara menurut Barnawi dan Arifin (2014:14), kinerja guru dapat diartikan sebagai tingkat keberhasilan guru dalam melaksanakan tugas pendidikan sesuai dengan tanggung jawab dan wewenangnya berdasarkan standar kinerja yang telah ditetapkan selama periode tertentu dalam kerangka mencapai tujuan pendidikanl. Standar kinerja ini terdapat di dalam Undang-Undang Republik Indonesia Nomor 14 Tahun 2005 pasal 8 tentang Guru dan Dosen bahwa — guru wajib memiliki kualifikasi akademik, kompetensi, sertifikat pendidik, sehat jasmani dan rohani, serta memiliki kompetensi untuk mewujudkan tujuan pendidikan nasional

Berdasarkan pengertian di atas dapat penulis definisikan bahwa kinerja guru adalah hasil yang telah didapatkan oleh seseorang (guru) dalam melaksanakan tugas dan tanggung jawabnya. Dan pada prinsipnya kinerja mengarah pada suatu upaya dalam rangka mencapai prestasi kerja yang lebih baik.

\section{Faktor yang mempengaruhi kinerja guru}

Ada banyak faktor yang dapat mempengaruhi kinerja individu. Menurut Supardi (2013:47) faktor yang dapat mempengaruhi mutu kinerja seseorang antara lain: (1) partsisipasi SDM; (2) pengembangan karir; (3) komunikasi, kesehatan dan keselamatan kerja; (4) penyelesaian konflik; (5) intensif yang baik, dan; (6) kebanggaan. Berbeda dengan pandangan Supardi, menurut Locke and Latham (1990) dalam Supardi (2013:48) kinerja seseorang secara individual ditentukan oleh beberapa bidang sebagai berikut: (1) kemampuan (ability); (2) komitmen (commitment); (3) umpan balik (feedback); (4) kompleskitas kerja (task complexity); (4) kondisi yang menghambat (situasional constraint); (5) tantangan (challenge); (6) tujuan (goal); (7) fasilitas, keakuratan dirinya (self-afficacy); (8) arah (direction) dan usaha (effort); (9) daya tahan/ketekunan (persistence); (10) strategi khusus 
dalam menghadapi tugas (task strategies). Sedangkan Suhardiman (2012) dalam Kompri (2014:163) menjelaskan bahwa ada tiga faktor yang mempengaruhi kinerja guru, yaitu: (1) kemampuan, (2) upaya dan (3) peluang atau kesempatan.

\section{Supervisi Kepala sekolah}

Supervisi merupakan kegiatan yang dilakukan oleh kepala sekolah untuk membantu guru dalam mengembangkan kemampuannya dan memfasilitasi guru dalam usaha memperbaiki proses pembelajaran (Mulyasa, 2011:252). Menurut Purwanto (2010:76) supervisi adalah aktivitas pembinaan yang direncanakan untuk membantu para guru dan pegawai sekolah lainnya dalam melakukan pekerjaan mereka secara efektif.

Berdasarkan pengertian di atas dapat disimpulkan bahwa supervisi proses pembinaan secara profesional yang dilakukan oleh kepala sekolah yang memiliki tujuan untuk meningkatkan profesionalisme guru dalam melaksanakan tugas pembelajaran.

\section{Model-model Supervisi}

Beberapa model supervisi yang dapat dilakukan oleh para supervisor dalam melakukan supervisi antara lain:

a. Supervisi Konvensional (Tradisional)

Menurut Sahertian (2008:35) supervisi konvensional ini pimpinan cenderung mencari-cari kesalahan, perilaku supervisi dengan mengadakan inspeksi untuk mencari dan menemukan kesalahan.

b. Supervisi Umum

Supervisi umum adalah supervisi yang dilakukan terhadap kegiatan-kegiatan atau pekerjaan yang secara langsung tidak berhubungan dengan usaha perbaikan pengajaran, seperti supervisi terhadap pengelolaan bangunan dan perlengkapan sekolah atau kantor-kantor pendidikan, supervisi terhadap kegiatan pengelolaan administrasi kantor dan supervisi keuangan sekolah.

c. Supervisi Akademik atau Supervisi Klinis

Supervisi klinis menurut Sudjana (2008:50) adalah bantuan profesional yang diberikan kepada guru yang mengalami masalah dalam pembelajaran agar guru yang bersangkutan dapat mengatasi masalahnya dengan menempuh langkah yang sistematis mencakup tahap perencanaan, tahap pengamatan, tahap analisis dan tindak lanjut. 
d. Supervisi Kolegial atau Kesejawatan

Supervisi kolegial atau kesejawatan bisa dimasukkan ke dalam teknik supervise kelompok.

\section{Teknik Supervisi}

Teknik supervisi menurut Sagala (2009:210) bahwa teknik supervisi ada dua yaitu:

a. Teknik supervisi yang bersifat kelompok, antara lain dengan cara pertemuan orientasi, rapat guru latih, studi kelompok antar guru latih, diskusi sebagai proses kelompok, tukar menukar pengalaman, lokakarya, laboratorium kurikulum, dan melakukan perjalanan sekolah.

b. Teknik supervisi yang bersifat individual. Teknik ini dapat dilakukan dengan cara kunjungan kelas, observasi kelas, percakapan pribadi, inter-visitasi, penyeleksi berbagai sumber materi untuk mengajar, menilai diri sendiri, diskusi panel, seminar, symposium, demonstrasi mengajar, perpustakaan jabatan, bulletin supervisi, membaca langsung, mengikuti kursus dan kegiatan-kegiatan organisasi dalam jabatan.

\section{METODE}

Metode penelitian yang digunakan dalam penelitian ini adalah survey. Jumlah populasi penelitian ini adalah Guru SMP K 1 Penabur yang berjumlah 35 guru. Teknik sampling yang digunakan adalah sampling jenuh dengan mengambil sampel keseluruhan dari jumlah populasi yaitu sebanayak 35 guru. Teknik pengumpulan data penelitian berupa wawancara, observasi, dan menggunakan kuesioner (angket). Teknik analis data yang digunakan adalah uji regresi sederhana, uji koefisien korelasi dan untuk menguji hipotesis penelitian menggunakan uji t.

\section{HASIL DAN PEMBAHASAN}

Hasil rekapitulasi penelitian dengan judul Pengaruh Supervisi Kepala Sekolah terhadap Kinerja Guru Di Smp K 1 Penabur Pasar Baru Jakarta Pusat sebagai berikut:

Tabel 1. Hasil rekapitulasi data penelitian

\begin{tabular}{|l|l|l|l|l|l|}
\hline $\mathrm{N}$ & $\sum \mathrm{X}$ & $\sum \mathrm{Y}$ & $\sum \mathrm{X}^{2}$ & $\sum \mathrm{Y}^{2}$ & $\sum \mathrm{XY}$ \\
\hline Jumlah & $\mathbf{3 . 1 4 2}$ & $\mathbf{3 . 2 3 7}$ & $\mathbf{2 8 3 . 1 3 2}$ & $\mathbf{3 0 0 . 5 7 5}$ & $\mathbf{2 9 1 . 3 8 8}$ \\
\hline
\end{tabular}




\section{Uji regresi sederhana}

Uji regresi linier sederhana adalah hubungan secara linear antara satu variabel independen $(\mathrm{X})$ dengan variabel dependen $(\mathrm{Y})$. Uji ini untuk mengetahui arah hubungan antara variabel independen dengan variabel dependen apakah positif atau negatif dan untuk memprediksi nilai dari variabel dependen apabila nilai variabel independen mengalami kenaikan atau penurunan.

Berdasarkan hasil uji regresi liner sederhana didapat kan persamaan regresinya adalah $\mathrm{Y}=25,555+0,746 \mathrm{X}$. Artinya, terdapat pengaruh yang positif supervisi kepala sekolah terhadap kinerja guru. Hal ini ditunjukan dengan diperolehnya nilai koefisien regresi sebesar 0,746. Nilai sebesar 0,746 menunjukan bahwa setiap perubahan 1 poin variabel supervisi kepala sekolah (X) maka akan diimbangi dengan perubahan variabel kinerja guru (Y) sebesar 25,555.

\section{Uji Koefisien Korelasi}

Dari hasil perhitungan analisis di atas diperoleh nilai $r=0,7045$ hal ini berarti terdapat hubungan yang positif dan kuat antara supervisi kepala sekolah dengan kinerja guru. Dari hasil perhitungan koefisien korelasi dapat dihitung pula besarnya kontribusi variabel bebas terhadap variabel terikat dengan menggunakan rumus koefisien determinasi. Hasil perhitungan didapatkan koefisien determinasinya adalah 49,63\%. Nilai persentase tersebut menunjukkan bahwa supervisi kepala sekolah memberikan kontribusi dalam meningkatkan kinerja guru sebesar 49,63\% sedangkan sisanya 50,37\% dipengaruhi oleh faktor-faktor lain yang tidak diteliti dalam penelitian ini.

\section{Uji Hipotesis Penelitian (Uji t)}

Pengujian hipotesis dimaksudkan untuk membuktikan apakah hipotesisyang diujikan diterima atau tidak, maka perlu dilakukan uji hipotesis dengan $\alpha=5 \%$.

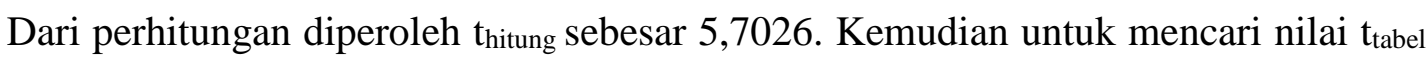
dapat digunakan tabel t, dimana pada tarif signifikan 0,025 (uji dua sisi) sebesar $2.5 \%$ dan derajat kebebasan $(\mathrm{dk}=\mathrm{n}-2)(35-2=33)$, maka akan diperoleh $\mathrm{t}_{\text {tabel }}=2,0345$. Untuk hasil perhitungan diatas menghasilkan $t_{\text {hitung }}$ lebih besar dibandingkan $t_{\text {tabel }}$ ini berarti hipotesis Ho ditolak sedangkan Ha diterima. Dapat disimpulkan bahwa supervisi kepala sekolah berpengaruh terhadap kinerja guru SMP K 1 Penabur. 
Research and Development Journal of Education

Vol. 3 No.1 Oktober 2016

ISSN 2406-9744

\section{DAFTAR PUSTAKA}

Barnawi dan Mohammad Arifin. 2014. Kinerja Guru Profesional: Instrumen Pembinaan, Peningkatan dan Penilaian. Jogjakarta: AR-RUZZ MEDIA.

Kompri. 2014. Manajemen Sekolah: Teori dan Praktik. Bandung: ALFABETA

Nimpuno, dkk. 2014. Kamus Bahasa Indonesia (Edisi Baru). Jakarta: Pandom Media Nusantara.

Mulyasa. 2011. Standar Kompetensi dan Sertifikasi Guru. Bandung: PT. Remaja Rosdakarya

Priansa, Donni Juni. 2014. Kinerja dan Profesionalisme Guru. Bandung: ALFABETA.

Purwanto, Ngalim. 2010. Psikologi Pendidikan. Jakarta: Remaja Rosdakarya.

Rachmawati, Tutik. 2013. Penilaian Kinerja Profesi Guru dan Angka Kreditnya. Yogyakarta: GAVA MEDIA.

Sahertian, Piet. 2008, Supervisi Pendidikan dalam Rangka Inservice Education, Jakarta: Rineka Cipta

Sagala, Syaiful. 2011. Konsep dan Makna Pembelajaran. Bandung: CV. Alfabeta.

Sudjana, Nana. 2008. Penilaian Hasil Proses Belajar Mengajar. Jakarta : Rosda

Supardi. 2013. Kinerja Guru. Jakarta: Rajawali Pers.

Uno, Hamzah B dan Nina Lamatenggo. 2012. Teori Kinerja dan Pengukurannya. Jakarta: Bumi Aksara. 